\title{
Pesan Kampanye Hitam dalam Media (Analisis Isi Kuantitatif pada Tayangan Debat Publik Pemilihan Gubernur dan Wakil Gubernur Jawa Barat 2018) Black Campaign Message in the Media (Quantitative Content Analysis on Public Debate Shows West Java Governor and Deputy Governor Election 2018)
}

\author{
Lolly Octarina ${ }^{1}$ dan Kharisma Nasionalita ${ }^{2 *}$ \\ 1,2Universitas Telkom \\ Email: octarinalolly10@gmail.com ${ }^{1}$ dan nasionalita.kharisma@gmail.com² ${ }^{2 *}$ \\ *corresponding author
}

Keywords:

Black Campaign Message, Content Analysis, General Election of West Java Governor
Kata Kunci:

Pesan Kampanye Hitam, Analisis Isi, Pemilihan Umum Gubernur Jawa Barat

\begin{abstract}
Black campaigns are a phenomenon that is attracting the attention of the current government. This phenomenon is the higher the intensity, namely in the implementation of regional elections. West Java is the province with the highest number of voters in 2018. This study uses quantitative content analysis methods. This study is to find out the percentage of black campaign messages seen in the debates on the election of the governor and deputy governor of West Java show. The results of the study are black campaign messages with the highest percentage in the category of insulting that is $53.85 \%$ (percent), followed by defaming $15.38 \%$ (percent), spreading false news $15.38 \%$ (percent), inciting $15.38 \%$ ( percent), and pitting sheep $0 \%$ (percent). The most content of black campaign message found was insulting message from the candidates. Some of these messages were out of context or not related to the theme discussed during the debate and related to black campaign messages theory. Moreover, the message violates the Republic of Indonesia Law concerning the Election of Governors, Regents and Mayors. So, the message on the show shows that the community is not well educated because the message delivered contains black campaign content.
\end{abstract}

\begin{abstract}
ABSTRAK
Kampanye hitam adalah fenomena yang menarik perhatian pemerintah saat ini. Fenomena ini semakin tinggi intensitasnya yaitu dalam pelaksanaan pilkada. Jawa Barat merupakan provinsi dengan pemilih tetap terbanyak pada tahun 2018. Penelitian ini menggunakan metode analisis isi kuantitatif. Penelitian ini untuk mengetahui persentase pesan kampanye hitam yang tampak dalam tayangan debat pemilihan gubernur dan wakil gubernur Jawa Barat 2018. Dari hasil penelitian ini terdapat pesan kampanye hitam dengan persentase tertinggi pada kategori menghina yaitu 53,85\% (persen), lalu diikuti memfitnah 15,38\% (persen), menyebarkan berita bohong 15,38\% (persen), menghasut 15,38\% (persen), dan mengadu domba 0\% (persen). Konten pesan kampanye hitam paling banyak yaitu penghinaan yang dilakukan antar kandidat. Pesan tersebut merupakan pesan diluar konteks atau tidak berkaitan dengan tema yang dibahas pada saat debat dan berkaitan dengan teori kampanye hitam. Selain itu, pesan tersebut telah melanggar Undang-Undang Tentang Pemilihan Gubernur, Bupati, dan Walikota. Sehingga, dengan pesan yang ada pada tayangan menunjukkan bahwa masyarakat kurang teredukasi dengan baik karena pesan yang disampaikan mengandung koten kampanye hitam.
\end{abstract}

Copyright (C) 2019 Channel Jurnal Komunikasi. All right reserved. 


\section{PENDAHULUAN}

Tahun 2018, Indonesia tengah menyambut tahun politik. Pelaksanaan pemilihan kepala daerah (disingkat pilkada) tahun 2018 dilaksanakan pada 26 Juni 2018 untuk memilih calon gubernur dan wakil gubernur masa bakti 2018-2023. Pilkada tidak terlepas dari aktivitas kampanye. Terjadi transformasi dalam komunikasi politik (kampanye) dari metode kampanye yaitu dengan adanya penggunaan media. Menurut Nasrullah (2015: 4) bahwa media memiliki kekuatan yang juga berkontribusi menciptakan makna dan budaya. Media berperan besar dalam melatarbelakangi perubahan perilaku politik masyarakat sebagai alat untuk memenuhi kebutuhan masyarakat akan informasi mengenai para calon kandidat. Sebab, pengetahuan masyarakat mengenai para kandidat yang hendak dipilih sangatlah penting untuk mengetahui mana calon yang layak untuk dipilih dan menjadi pemimpin daerahnya. Kampanye hitam pada kasus pemilu sebelumnya menarik perhatian masyarakat seperti yang telah diteliti oleh La Jannuru (2016) pada penelitian berjudul "Analisis Wacana Black Campaign (Kampanye Hitam) pada Pilpres Tahun 2014 di Media Kompas, Jawa Pos dan Kedaulatan Rakyat”. Dari hasil penelitiannya ditemukan bahwa dampak kampanye hitam dalam pilpres tahun 2014 dapat terlihat dari beberapa indikator yaitu pertama, menjatuhkan nama baik seorang calon presiden menyebabkan yang bersangkutan tidak disenangi oleh rekan separtainya, pendukungnya, dan masyarakat umum. Kedua, mematikan karakter calon presiden dengan mengungkap aib calon yang ada sehingga yang bersangkutan kehilangan simpatik sehingga akan berdampak pada menurunnya elektabilitas calon presiden yang bersaing dalam pilpres. Selain itu, penelitian lainnya juga dilakukan oleh Lilian Oktaviani (2015) yang berjudul "Pengaruh Kampanye Hitam Melalui Media Massa Terhadap Pilihan Pemilih Pemula Pada Pilpres 2014 (Studi Pada Dusun Purworejo Dan Srirejo Kelurahan Branti Raya Kecamatan Natar)". Dari hasil penelitian tersebut ditemukan terdapat pengaruh antara kampanye hitam melalui media massa terhadap pilihan pemilih pemula dan memiliki hubungan yang searah. Di mana jika semakin meningkat intensitas kegiatan atau pemberitaan yang dilakukan berulang-ulang maka akan mempengaruhi pilihan pemilih pemula. Dimana hubungan antara kampanye hitam melalui media massa terhadap pilihan pemilih pemula memiliki hubungan yang searah atau linier dan kampanye hitam melalui media massa mempunyai pengaruh terhadap pilihan pemilih pemula), yang berarti semakin tinggi intensitas pemberitaan kampanye hitam mengakibatkan berubahnya pilihan pemilih pemula. Sehingga disimpulkan bahwa kampanye hitam juga memiliki peran terhadap pilihan pemilih pemula.

Pada dasarnya, kampanye dilakukan untuk mengutarakan ide-ide terbaik yang dapat dirumuskan sehingga disampaikan kepada masyarakat dan diterima dengan baik bahkan mendapat dukungan oleh masyarakat. Namun di era sekarang ini, banyak sekali kegiatan kampanye yang dilakukan untuk menyerang lawan politik (attacking campaign) bahkan menjatuhkan lawan dalam politik. Salah satu fenomena politik yang banyak diperbincangkan masyarakat saat ini adalah kampanye hitam. Dahulu kampanye hitam dikenal sebagai whispering campaign melalui mulut ke mulut, namun sekarang bisa dengan menggunakan media elektronik. Secara harfiah kampanye hitam bisa dikatakan sebagai strategi menyampaikan pesan yang memiliki fakta secara sepihak sehingga pesan tersebut digunakan untuk membuat citra kandidat lain tampak buruk dan ditujukan oleh satu kadidat kepada kandidat lainnya untuk menjatuhkannya dimata publik. Intensitas kampanye hitam ini makin meningkat dengan adanya pilkada atau pemilihan kepala daerah. Masalah ini kerap muncul karena kelompok pendukung calon tertentu berseberangan dengan kelompok pendukung calon lainnya. Di perhelatan pilkada 2018 ini isu kampanye hitam menjadi perbincangan hangat di masyarakat. Bahkan dilansir dari republika.co.id (Kamis, 01/02/2018) bawaslu mengatakan bahwa kampanye hitam menjadi isu penting dalam pilkada 2018 ini (www.republika.co.id, diakses pada 18 Januari 2018, pukul 16.31). Bahkan dilakukan berbagai upaya pencegahan yang dilakukan pemerintah dengan diadakannya pengawasan terhadap penggunaan media sosial oleh Bawaslu, KPU, dan Menkominfo untuk pencegahan kampanye hitam ini karena pelaksanaan pilkada ini dianggap sangat rawan kampanye hitam. Dari upaya tersebut dapat dilihat bahwa pada kampanye hitam adalah salah satu masalah yang menjadi perhatian pemerintah dalam pilkada 2018 ini.

Berdasarkan data infopemilu.kpu.go.id, bahwa pada tahun 2018 pulau Jawa memiliki jumlah pemilih tetap paling banyak yang terdiri dari beberapa provinsi yaitu Jawa Barat memiliki jumlah pemilih tetap yaitu 31.730.039 orang, Jawa Timur dengan jumlah pemilih tetap 30.155.719 orang, Jawa Tengah sejumlah 27.068.500 orang, dan Banten sejumlah 4.219.124 orang (infopemilu.kpu.go.id, diakses pada 6 Juli 2018, pukul 15.00). Jawa Barat memiliki jumlah pemilih tetap terbanyak pada tahun 2018 yaitu sebanyak 30.155.719 orang dibandingkan dengan provinsi lainnya. Dengan jumlah tersebut menggambarkan bahwa Jawa Barat memiliki peran yang sangat besar dalam perhelatan pilkada ini. Besarnya jumlah pemilih tetap di Jawa Barat menjadikan provinsi ini mendapat perhatian dalam pilkada ini.

Selama masa kampanye berlangsung, debat publik pemilihan gubernur dan wakil gubernur Jawa Barat 2018 salah satu wujud pelaksanaan agenda politik yang disiarkan melalui televisi swasta nasional. Namun, pada debat publik pemilihan gubernur dan wakil gubernur di Jawa Barat 2018 kali ini terdapat insiden yang membuat heboh masyarakat yaitu pada tayangan debat publik pemilihan gubernur dan wakil gubernur Jawa Barat 2018. Pada tayangan debat pemilihan gubernur dan wakil gubernur Jawa Barat 2018 terdapat beberapa pesan di luar konteks penyampaian visi dan misi atapun program kerja yang disampaikan oleh satu kandidat kepada kandidat yang lain. Seperti ketika Deddy Mizwar mengritik pertanyaan yang disampaikan oleh Ridwan Kamil dengan mengatakan Ridwan Kamil memiliki pengetahuan yang kurang. 
Selain itu pada tayangan putaran kedua, terdapat insiden "2019 Ganti Presiden” turut mewarnai panggung debat pemilihan gubernur dan wakil gubernur Jawa Barat 2018. Pada debat tersebut sempat terjadi kericuhan di tengah pelaksanaan debat dengan munculnya closing statement dari pasangan calon gubernur dan wakil gubernur nomor 4 (Sudrajat-Syaikhu). Hal tersebut cukup membuat masyarakat resah karena terdapat beberapa pesan yang dianggap melanggar aturan dalam berkampanye yang disampaikan oleh pasangan calon gubernur dalam debat pemilihan gubernur dan wakil gubernur Jawa Barat 2018. Dilansir dari pikiran-rakyat.com menyatakan, lembaga yang berfungsi dalam pengawasan pemilu (Bawaslu) telah menyatakan tindakan tersebut merupakan pelanggaran dan merekomendasikan KPU untuk memberi teguran kepada pelaku pelanggaran kampanye dalam debat publik tersebut (www.pikiran-rakyat.com, diakses pada 10 Juli 2018, pukul 19.17). Dari pemaparan latar belakang di atas, penulis tertarik untuk menganalisis lebih dalam mengenai analisis isi pesan kampanye hitam pada tayangan debat publik pemilihan gubernur dan wakil gubernur Jawa Barat 2018. Oleh karena itu, latar belakang di atas mendorong peneliti untuk melakukan penelitian dengan judul, "Pesan Kampanye Hitam dalam Media (Analisis Isi Kuantitatif pada Tayangan Debat Publik Pemilihan Gubernur dan Wakil Gubernur Jawa Barat 2018)".

\section{RUMUSAN MASALAH}

Apakah ada konten pesan kampanye hitam dalam tayangan debat publik pemilihan gubernur dan wakil gubernur Jawa Barat 2018 terkait kategori berikut:

1. Berapa persentase konten pesan kampanye hitam dalam tayangan debat publik pemilihan gubernur dan wakil gubernur Jawa Barat 2018 terkait penghinaan?

2. Berapa persentase konten pesan kampanye hitam dalam tayangan debat publik pemilihan gubernur dan wakil gubernur Jawa Barat 2018 terkait fitnah?

3. Berapa persentase konten pesan kampanye hitam dalam tayangan debat publik pemilihan gubernur dan wakil gubernur Jawa Barat 2018 terkait adu domba?

4. Berapa persentase konten pesan kampanye hitam dalam tayangan debat publik pemilihan gubernur dan wakil gubernur Jawa Barat 2018 terkait hasutan?

5. Berapa persentase konten pesan kampanye hitam dalam tayangan debat publik pemilihan gubernur dan wakil gubernur Jawa Barat 2018 terkait menyebarkan berita bohong?

\section{KAJIAN PUSTAKA}

\section{A. Komunikasi}

Menurut Bernard Barelson dan Gary A. Steiner (dalam Mulyana, 2011:68) mengatakan bahwa komunikasi merupakan transmisi informasi, gagasan, emosi, keterampilan, dan sebagainya dengan menggunakan simbol-simbol (kata-kata, gambar, figur, grafik, dan sebagainya). Tindakan atau proses transmisi tersebut disebut komunikasi. Carl I. Hovland (dalam Mulyana, 2011:68)juga mengatakan bahwa komunikasi adalah proses yang seseorang (komunikator) menyampaikan rangsangan (biasanya lambang-lambang verbal) untuk mengubah perilaku orang lain (komunikate). Dengan begitu komunikator menyampaikan pesan dengan tujuan agar komunikan (penerima pesan) dapat mempunyai pemahaman yang sama dan dapat terjadi perubahan perilaku pada komunikan. Mulyana (2011:69) mengatakan bahwa untuk menyampaikan apa yang ada dalam hatinya (perasaan atau pikiran), sumber harus mengubah perasaan atau pikiran tersebut ke dalam seperangkat simbol pesan verbal atau non verbal yang idealnya dipahami oleh penerima pesan proses ini disebut penyandian (encoding). Dari beberapa paparan teori oleh para ahli tersebut dapat disimpulkan bahwa komunikasi sebagai suatu proses yang terjadi oleh komunikan kepada komunikator baik secara individu, kelompok, atau bahkan dalam jumlah yang sangat besar dalam menyampaikan perasaan, ide, gagasan, atau pikirannya dengan tujuan terjadi pemahaman yang sama dan perubahan pada penerima pesan (komunikan). Untuk menyampaikan pesan tersebut dapat dengan cara verbal atau nonverbal sebagai instrumen untuk menyalurkan perasaan komunikator sehingga dapat dipahami oleh penerima pesan dan mengurangi adanya resiko kesalahpahaman terhadap pesan tersebut.

\section{B. Komunikasi Politik}

Menurut Nimmo (2011: 8) politik adalah siapa memperoleh apa, kapan, dan bagaimana pembagian nilai-nilai oleh yang berwenang, kekuasaan dan pemegang kekuasaan, pengaruh tindakan yang diarahkan untuk mempertahankan dan atau memperluas tindakan lainnya. Dari yang dikemukakan oleh Nimmo, politik merupakan suatu nilai-nilai oleh yang berwenang dan berkuasa siapa pun itu apa yang akan diperoleh dari nilai tersebut serta cara menyebarluaskan nilai tersebut agar dapat memengaruhi tindakan orang lainnya sesuai apa yang diinginkan. Menurut Gabriel Almond (dalam Wahid, 2016: 12) komunikasi politik adalah salah satu fungsi yang selalu ada dalam setiap sistem politik, berkaitan dengan ketertarikan mengenai isu-isu politik, pembuatan peraturan politik, aturan aplikasi, dan aturan-aturan lainnya yang melibatkan proses serta tindakan komunikasi. McNair (dalam Wahid, 2016: 13) mengatakan memberi batasan atau definisi komunikasi politik yaitu pertama, semua bentuk komunikasi yang digunakan oleh politikus dan aktor atau tokoh politik lainnya untuk mencapai tujuan yang ditetapkan. Kedua, komunikasi yang disampaikan oleh aktor atau pelaku 
politik nonpolitikus, seperti pemilih (voters) dan kolumnis. Ketiga, komunikasi mengenai para aktor atau pelaku politik dan aktivitasnya seperti pada berita, editorial, dan bentuk lainnya dari media politik.

\section{Kampanye}

Rogers dan Storey (dalam Venus, 2009:7), kampanye merupakan serangkaian aktifitas komunikasi yang terorganisasi agar menciptakan efek tertentu pada sejumlah besar khalayak yang dilakukan secara berkelanjutan pada kurun waktu tertentu. Venus (2009:70) dikatakan bahwa kampanye pada dasarnya adalah penyampaian pesan-pesan dari pengirim kepada khalayak melalui media saluran dengan menggunakan simbol, baik verbal maupun nonverbal yang bertujuan dapat memancing respon khalayak. Pada aktivitas kampanye komunikasi mengandung hal-hal berikut yaitu tindakan kampanye yang dituju untuk menciptakan efek atau dampak tertentu, sasaran khalayak dengan jumlah besar, dipusatkan dalam kurun waktu tertentu, dan melalui serangkaian tindakan komunikasi secara terorganisasi.

\section{Kampanye Hitam}

Kampanye hitam merupakan perilaku kampanye yang dilakukan dengan menghina, memfitnah, mengadu domba, menghasut, atau menyebarkan berita bohong yang dilakukan oleh seorang calon, sekelompok orang, partai politik, pendukung seorang calon terhadap lawan atau calon lainnya (Haboddin, 2017:75).

Pada kenyataannya pelaksanaan kampanye telah memiliki aturan tersendiri berdasarkan Undang-Undang Republik Indonesia Nomor 1 Tahun 2015 Tentang Pemilihan Gubernur, Bupati, dan Walikota. Pada bagian kelima pasal 69 tentang larangan kampanye yaitu:

1. Mempersoalkan dasar negara Pancasila dan Pembukaan Undang-Undang Dasar Negara RI tahun 1945;

2. Menghina seseorang, agama, suku, ras, golongan, calon gubernur, calon bupati, calon walikota, dan/atau partai politik;

3. Melakukan kampanye berupa menghasut, memfitnah, mengadu domba partai politik, perseorangan, dan/atau kelompok masyarakat;

4. Mengunakan kekerasan, ancaman kekerasan atau menganjurkan penggunaan kekerasan kepada perseorangan, kelompok masyarakat dan/atau partai politik;

5. Mengganggu keamanan, ketentraman, dan ketertiban umum;

6. Mengancam dan menganjurkan penggunaan kekerasan untuk mengambil alih kekuasaan dari pemerintah yang sah;

7. Merusak dan/atau menghilangkan alat peraga kampanye;

8. Menggunakan fasilitas dan anggaran pemerintah dan pemerintah daerah;

9. Menggunakan tempat ibadah dan tempat pendidikan

10. Melakukan pawai yang dilakukan dengan berjalan kaki dan/atau dengan kendaraan di jalan raya; dan/atau

11. Melakukan kegiatan kampanye di luar jadwal yang telah ditetapkan oleh KPU Provinsi dan KPU Kabupaten /Kota.

Berdasarkan definisi kampanye hitam menurut Haboddin (2017), berikut ini adalah penjelasan bentuk-bentuk kampaye hitam adalah sebagai berikut.

a. Penghinaan

Berdasarkan Kitab Undang-Undang Hukum Pidana Bab XVI tentang penghinaan pasal (1) yang berbunyi: "Barang siapa sengaja menyerang kehormatan atau nama baik seseorang dengan menuduhkan sesuatu hal, yang maksudnya terang supaya hal itu diketahui umum, diancam karena pencemaran dengan pidana penjara paling lama sembilan bulan atau pidana denda paling banyak empat ribu lima ratus rupiah" (hukumpidana. bphn.go.id, diakses pada diakses pada 5 Juli 2018, pukul 19.00).

b. Memfitnah

Dalam KUHP diatur dalam pasal 311, yang menyebutkan bahwa, "Jika yang melakukan kejahatan pencemaran atau pencemaran tertulis, dalam hal dibolehkan untuk membutktikan bahwa apa yang dituduhkan itu benar, tidak membuktikannya dan tuduhan dilakukan bertentangan dengan apa yang diketahui, maka dia diancam karena melakukan fitnah, dengan pidana penjara paling lama empat tahun" (dalam Samudra, 2011).

Memfitnah yang berasal dari kata "fitnah" yang berarti perkataan bohong atau tanpa berdasarkan kebenaran yang disertakan dengan maksud menjelekkan orang (seperti menodai nama baik, merugikan kehormatan orang) (KBBI, 2008:393). Dalam hal ini memfitnah berarti menjelekkan nama orang (menodai nama baik, merugikan kehormatan).

c. Mengadu Domba

Imam Al-Ghazali menjelaskan bahwa adu domba adalah membeberkan sesuatu yang tidak suka untuk 
dibeberkan. Baik yang tidak suka adalah pihak yang dibicarakan atau pihak yang menerima berita, maupun pihak yang lainnya. Baik dengan ucapan, tulisan, tanda, ataupun isyarat (Al-Ghazali, 2005:166). Mengadu domba atau adu domba berarti menjadikan berselisih (bertikai) diantara pihak yang sepaham, menarungkan (mempertarungkan, memperlagakan) kita sama kita (KBBI, 2008:12).

d. Menghasut

Menghasut bukan berarti memaksa atau memberi perintah, namun berusaha menggunakan kata-kata agar orang lain bergerak dengan kemauan sendiri untuk melakukan sesuatu. Menggunakan kata-kata yang dipergunakan oleh si penghasut dapat secara langsung disebutkan perbuatan apa yang diharapkan untuk dilakukan oleh mereka yang dihasut. Tetapi mungkin juga perbuatan itu tidak disebutkan tetapi dapat mudah dimengerti perbuatan apa yang diharapkan itu (Prodjodikoro, 2008:152).

e. Menyebarkan berita bohong

Dalam UU ITE Pasal 28 ayat (1) disebutkan bahwa setiap orang dengan sengaja, dan tanpa hak menyebarkan berita bohong dan menyesatkan yang mengakibatkan kerugian konsumen dalam Transaksi Elektronik (jdih. kominfo.go.id, diakses pada diakses pada 15.00 .

\section{E. Kerangka Pemikiran}

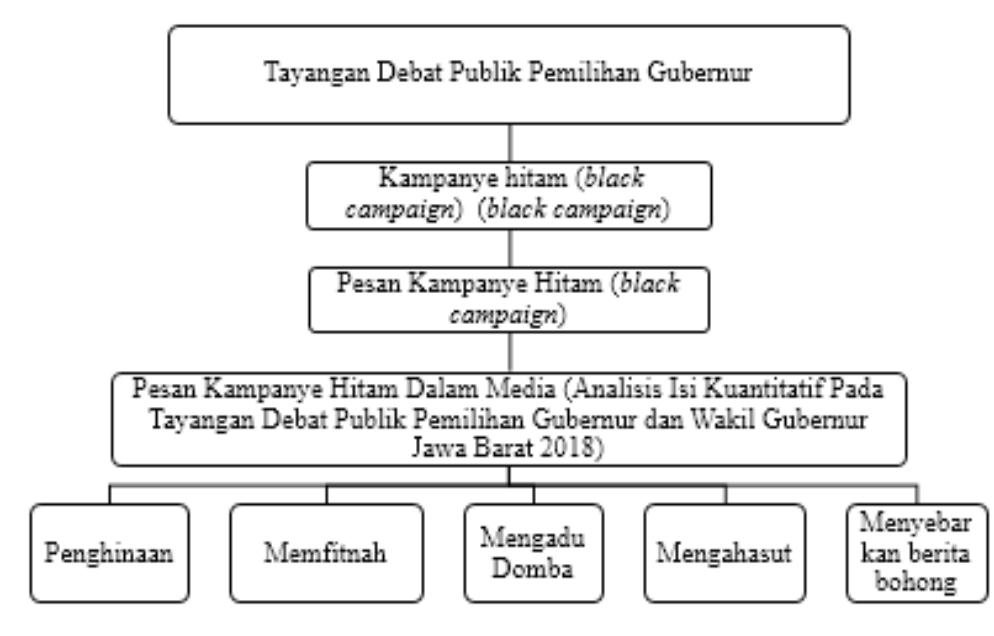

Gambar 2.1

Kerangka Pemikiran

Sumber: Olahan Data Penulis (2018)

Berdasarkan gambar 2.1 konten pesan kampanye hitam yang digunakan ada 5 yaitu penghinaan, memfitnah, mengadu domba, menghasut, dan menyebarkan berita bohong.

\section{METODE PENELITIAN}

Pada penelitian menggunakan metode analisis isi dengan jenis penelitian kuantitatif dimana penelitian kuantitatif merupakan penelitian yang menggunakan angka-angka yang dijumlahkan sebagai data dan kemudian dianalisis menurut Muijs (dalam Suharsaputra, 2012: 49). Sedangkan penelitian ini bersifat analisis deskripstif yang bertujuan untuk menggambarkan suatu pesan atau teks tertentu. Pesan yang dimaksud adalah isi komunikasi yaitu berupa bentuk-bentuk kampanye hitam sehingga peneliti mengukur atau menghitung aspek dari isi (content) yang terdapat dalam program tayangan "Debat Publik Pemilihan Gubernur dan Wakil Gubernur Jawa Barat 2018". Sebagai populasi dalam penelitian ini adalah seluruh program tayangan debat publik pemilihan gubernur dan wakil gubernur Jawa Barat 2018 kemudian sampel dalam penelitian ini adalah program tayangan debat publik pemilihan gubernur dan wakil gubernur Jawa Barat 2018 putaran pertama, kedua, dan ketiga. Maka dari itu, yang menjadi unit analisis dalam penelitian ini adalah pesan kampanye hitam. Penelitian ini adalah univariat, disebut univariat karena pengujian statistik ini didasarkan pada uji untuk satu variabel (Eriyanto, 2011:322), yaitu kampanye hitam. Dalam mengukur variabel tersebut peneliti menggunakan lembar coding. Agar mengetahui apakah alat ukur dapat dipercaya atau tidak, peneliti menggunakan formula Holsti. Formula Hoslti adalah uji reliabilitas antar-coder yang banyak dipakai selain persentase persetujuan (Eriyanto, 2011). Formula ini diperkenalkan oleh Ole R. Holsti (1969). Reliabilitas ditunjukkan dalam persentase persetujuan, berapa persen persentase persamaan antar-coder ketika menilai suatu isi. Rumus untuk menghitung reliabilitas adalah sebagai berikut:

$$
\text { Realibilitas Antar-Coder }(\mathrm{CR})=\frac{2 \mathrm{M}}{(\mathrm{N} 1+\mathrm{N} 2)}
$$


Di mana M adalah jumlah coding yang sama (disetujui oleh masing-masing coder), N1 adalah jumlah coding yang dibuat oleh coder 1, dan N2 adalah jumlah coding yang dibuat oleh coder 2. Reliabilitas bergerak antara 0 hingga 1, di mana 0 berarti tidak ada satu pun yang disetujui oleh para coder dan 1 berarti persetujuan sempurna di antara para coder. Makin tinggi angka, makin tinggi pula angka reliabilitas. Dalam formula Holsti, angka reliabilitas minimum yang ditoleransi adalah 0,7 atau 70 persen. Artinya, kalau hasil perhitungan menunjukkan angka reliabilitas di atas 0,7, berarti alat ukur ini benar-benar reliabel. Tetapi, jika di bawah angka 0,7, berarti alat ukur (coding sheet) bukan alat yang reliabel (Eriyanto, 2011:290). Pada penelitian ini, terdapat dua orang coder yaitu:

1. Peneliti sendiri (coder 1$)$

2. Aulia Fairuz (coder 2)

\section{HASIL PENELITIAN DAN PEMBAHASAN}

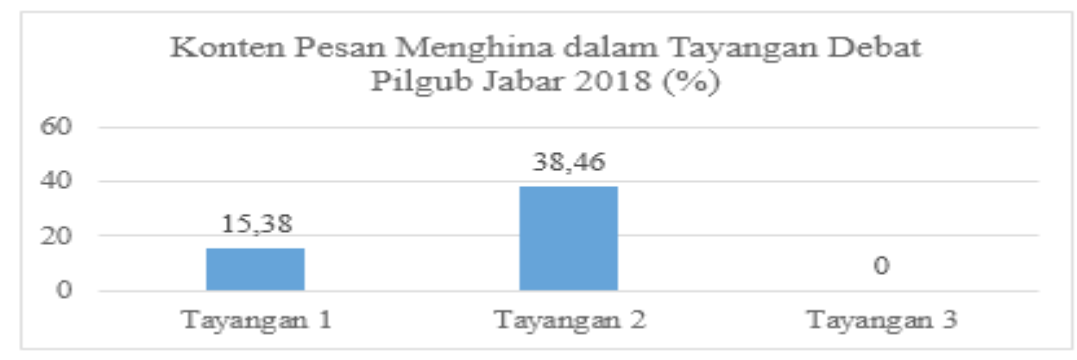

Gambar 4.1

Diagram Persentase Pesan Menghina di Tayangan Debat Pemilihan Gubernur dan Wakil Gubernur Jawa Barat 2018 Sumber: Olahan Peneliti

Dari hasil pengamatan peneliti yang dipaparkan melalui diagram diperoleh bahwa pesan kampanye hitam terkait pesan menghina pada tayangan putaran pertama sebesar 15,38\% (persen), putaran kedua sebesar 38,46\% (persen), dan putaran ketiga sebesar 0\% (persen). Dari persentase tersebut dapat dilihat bahwa ada terdapat pesan menghina dalam tayangan debat publik pemilihan gubernur dan wakil gubernur Jawa Barat 2018. Dengan tingkat kemunculan (frekuensi) pesan menghina paling tinggi adalah tayangan kedua yaitu $38,46 \%$ (persen).

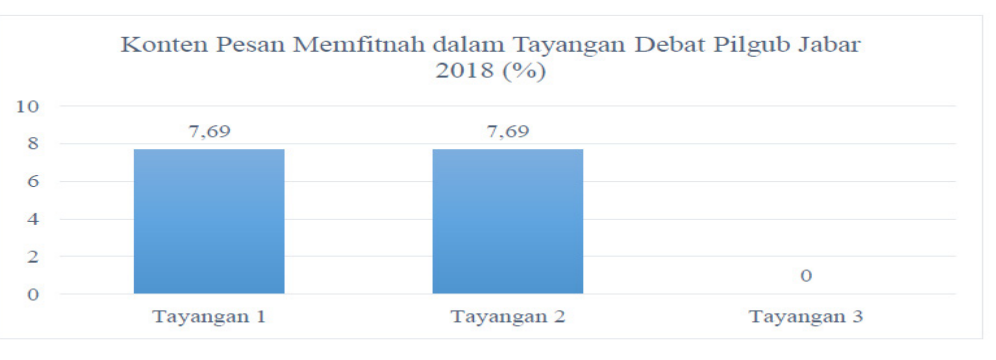

Gambar 4.2

Diagram Persentase Pesan Memfitnah dalam Tayangan Debat Pemilihan Gubernur dan Wakil Gubernur Jawa Barat 2018 Sumber: Olahan Peneliti

Kemudian hasil yang diperoleh banyaknya kandungan pesan kampanye hitam terkait pesan memfitnah terlihat dari diagram diatas bahwa pada tayangan putaran pertama sebesar 7, 69\% (persen), putaran kedua sebesar 7,69\% (persen), dan putaran ketiga sebesar 0\% (persen). Dari persentase tersebut dapat dilihat bahwa ada terdapat pesan memfitnah dalam tayangan debat publik pemilihan gubernur dan wakil gubernur Jawa Barat 2018. Dengan tingkat kemunculan (frekuensi) pesan memfitnah banyak muncul pada tayangan kesatu dan kedua yaitu 7, 69\% (persen). 


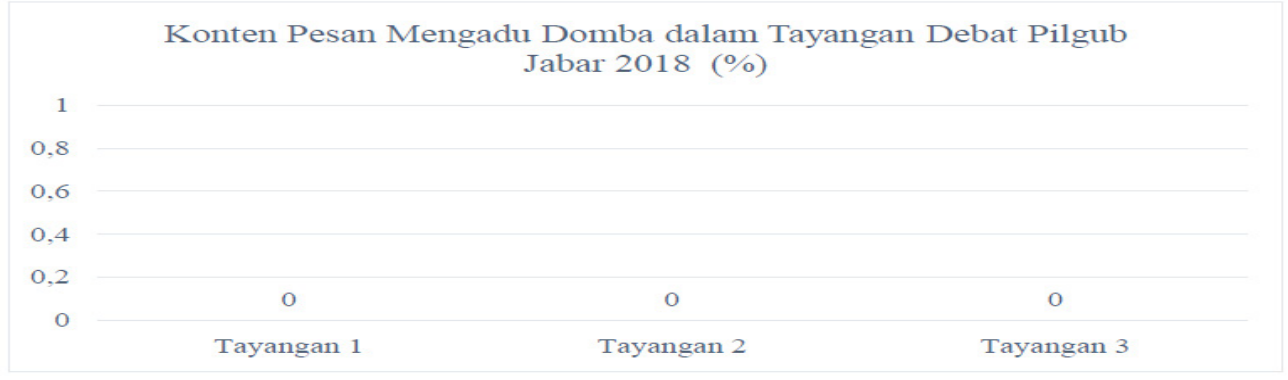

Gambar 4.3

Diagram Persentase Pesan Mengadu Domba dalam Tayangan Debat Pemilihan Gubernur dan Wakil Gubernur Jawa Barat 2018

Sumber: Olahan Peneliti

Kemudian untuk kategori pesan mengadu domba pada tayangan debat pemilihan gubernur dan wakil gubernur Jawa Barat 2018 dari hasil yang yang diperoleh yaitu putaran pertama sebesar $0 \%$ (persen), putaran kedua sebesar $0 \%$ (persen), dan putaran ketiga sebesar 0\% (persen). Dari persentase tersebut dapat dilihat bahwa tidak terdapat pesan mengadu domba dalam tayangan debat publik pemilihan gubernur dan wakil gubernur Jawa Barat 2018. Dimana memiliki kemunculan (frekuensi) pesan mengadu domba paling tinggi yaitu pada semua tayangan kedua yaitu $0 \%$ (persen).

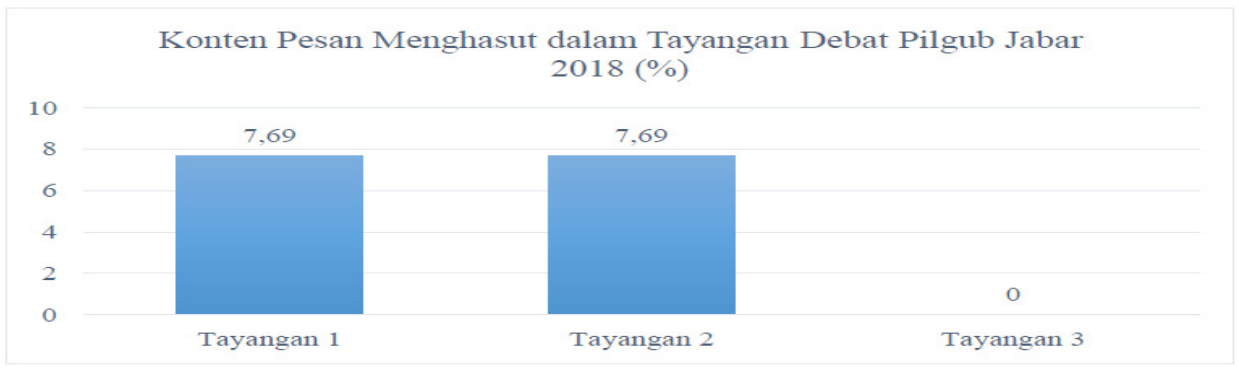

Gambar 4.4

Diagram Persentase Pesan Menghasut dalam Tayangan Debat Pemilihan Gubernur dan Wakil Gubernur Jawa Barat 2018 Sumber: Olahan Peneliti

Untuk kategori isi pesan kampanye hitam terhadap pesan menghasut ditemukan bahwa terdapat persentase pesan sebesar 7,69\% (persen) pada tayangan putaran pertama, 7,69\% (persen) pada tayangan putaran kedua, dan $0 \%$ (persen) pada tayangan putaran ketiga. Dari persentase tersebut dapat dilihat bahwa ada terdapat pesan menghasut dalam tayangan debat publik pemilihan gubernur dan wakil gubernur Jawa Barat 2018. Hal tersebut dilihat bahwa tayangan yang memiliki pesan menghasut yaitu putaran pertama dan kedua dengan tingkat kemunculan (frekuensi) pesan menghasut sama yaitu $7,69 \%$ (persen).

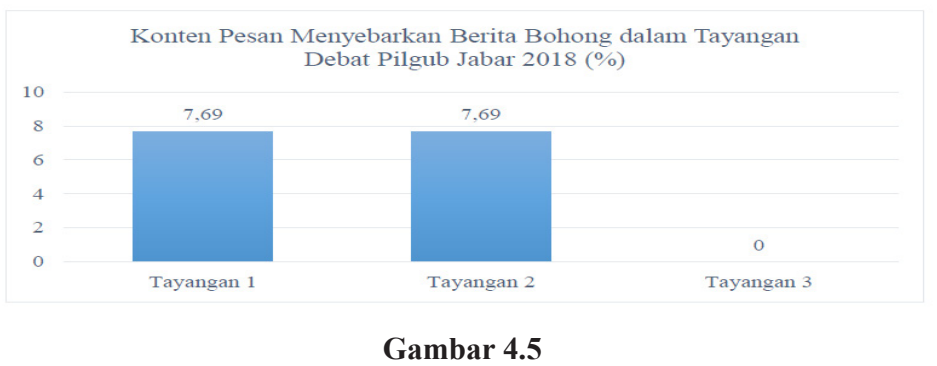

Diagram Persentase Pesan Menyebarkan Berita Bohong dalam Tayangan Debat Pemilihan Gubernur dan

Wakil Gubernur Jawa Barat 2018

Sumber: Hasil Olahan Peneliti

Selanjutnya yaitu menyebarkan berita bohong didapatkan hasil dari pesan menyebarkan berita bohong yaitu sebesar 7,69\% (persen) pada tayangan putaran pertama, 7,69\% (persen) pada tayangan putaran kedua, dan $0 \%$ (persen) pada tayangan putaran ketiga. Dari persentase tersebut dapat dilihat bahwa ada terdapat pesan menyebarkan berita bohong dalam tayangan debat publik pemilihan gubernur dan wakil gubernur Jawa Barat 2018. Tayangan yang memiliki pesan 
menyebarkan berita bohong yaitu putaran pertama dan kedua dengan tingkat kemunculan (frekuensi) pesan menghasut sama yaitu 7,69\% (persen).

Berdasarkan hasil temuan oleh peneliti dari tayangan debat publik pemilihan gubernur dan wakil gubernur Jawa Barat 2018 secara garis besar, dapat terlihat bahwa terdapat konten-konten pesan kampanye hitam. Konten pesan kampanye hitam terssebut terkait dengan pesan menghina, memfitnah, menghasut, dan menyebarkan berita bohong. Dari ketiga tayangan tersebut dari data yang telah diolah ditemukan bahwa konten pesan kampanye hitam yang paling banyak muncul ada pada tayangan putaran kedua sebesar 61,54\% (persen) dan dengan konten pesan kampanye hitam yang paling sedikit adalah tayangan putaran ketiga dimana tidak ditemukannya konten pesan yang termasuk ke dalam kampanye hitam yaitu $0 \%$ (persen).

Kampanye hitam dalam suatu debat publik gubernur dan wakil gubernur merupakan bagian dari komunikasi politik. Sebab menurut Subiakto dan Rachmah (2012: 19) suatu komunikasi yang kelihatannya pesan atau isinya bukan pesan politik, namun apabila secara potensial dan aktual dapat berakibat atau mempunyai konsekuensi pada salah satu sistem politik, maka itu adalah komunikasi politik. Pesan kampanye hitam akan memengaruhi pandangan masyarakat terhadap kandidat yang menyampaikan konten pesan kampanye hitam atau pun kandidat yang menjadi objek kampanye hitam tersebut. Sehingga tayangan debat publik pemilihan gubernur dan wakil gubernur Jawa Barat 2018 yang merupakan bagian dari kampanye dalam pelaksanaan pemilihan gubernur dan wakil gubernur karena dilaksanakan selama masa kampanye, akan berpengaruh terhadap pilihan masyarakat. Pada dasarnya kampanye politik merupakan salah satu upaya untuk meningkatkan popularitas dan elektabilitas aktor politik. Kampanye bukan sekadar proses lumrah dalam aktifitas politik, melainkan merupakan suatu proses dengan kesungguhan untuk melibatkan sebanyak mungkin khalayak agar berpastisipasi. Untuk itu, dari hasil penelitian dapat dinyatakan bahwa dalam tayangan program debat publik gubernur dan wakil gubernur Jawa Barat 2018 terdapat konten pesan kampanye hitam pada empat kategori yaitu menghina, memfitnah, menghasut, dan menyebarkan berita bohong. Sedangkan untuk kategori mengadu domba tidak ada ditemukan pesan yang terkait dengan kategori tersebut. Berarti dapat disimpulkan bahwa beberapa kandidat telah melakukan kampanye hitam yang berarti telah melanggar aturan kampanye yang telah dicantumkan di bab II tentang aturan pelaksanaan kampanye yaitu berdasarkan Undang-Undang Republik Indonesia Nomor 1 Tahun 2015 Tentang Pemilihan Gubernur, Bupati, dan Walikota. Pada bagian kelima pasal 69 huruf c tentang larangan kampanye yaitu dalam kampanye dilarang melakukan kampanye berupa menghasut, memfitnah, mengadu domba partai politik, perseorangan, dan/atau kelompok masyarakat. Sangat penting disadari oleh masyarakat untuk tidak mudah terpengaruh terhadap kampanye hitam. Maka dari itu, dengan adanya penyimpangan dalam pelaksanaan kampanye ini mengakibatkan masyarakat tidak teredukasi dengan baik sehingga banyak infomasi yang dapat terlewatkan oleh masyarakat.

\section{KESIMPULAN DAN SARAN}

\section{A. Kesimpulan}

Berdasarkan hasil penelitian yang diolah pada bab sebelumnya, serta mengumpulkan data yang telah dikoding dari tayangan debat publik pemilihan gubernur dan wakil gubernur Jawa Barat 2018 untuk menjawab pertanyaan pada rumusan masalah, maka dinyatakan bahwa dalam tayangan tersebut ditemukan terdapat konten pesan yang mengandung kampanye hitam. Persentase pada setiap kategori yaitu sebagai berikut:

1. Konten pesan kampanye hitam dalam tayangan debat publik pemilihan gubernur dan wakil gubernur Jawa Barat 2018 terkait penghinaan 53,85\% (persen)

2. Konten pesan kampanye hitam dalam tayangan debat publik pemilihan gubernur dan wakil gubernur Jawa Barat 2018 terkait memfitnah 15,38\% (persen).

3. Konten pesan kampanye hitam dalam tayangan debat publik pemilihan gubernur dan wakil gubernur Jawa Barat 2018 terkait mengadu domba $0 \%$ (persen).

4. Konten pesan kampanye hitam dalam tayangan debat publik pemilihan gubernur dan wakil gubernur Jawa Barat 2018 terkait menghasut 15,38\% (persen).

5. Konten pesan kampanye hitam dalam tayangan debat publik pemilihan gubernur dan wakil gubernur Jawa Barat 2018 terkait menyebarkan berita bohong 15,38\% (persen).

Konten pesan kampanye hitam yang ditemukan dalam tayangan debat publik pemilihan gubernur dan wakil gubernur Jawa Barat 2018 paling banyak yaitu terkait pesan penghinaan yang dilakukan antar kandidat. Hal ini disebabkan karena ada beberapa pesan yang disampaikan oleh para kandidat kepada pasangan lain yang diluar konteks atau tidak berkaitan dengan tema yang dibahas pada saat debat. Dari pesan-pesan yang tidak berkaitan tersebut ternyata memiliki keterkaitan dengan teori kampanye hitam yang telah dijelaskan. Selain itu, pesan tersebut telah melanggar Undang-Undang Republik Indonesia Nomor 1 Tahun 2015 Tentang Pemilihan Gubernur, Bupati, dan Walikota bagian kelima pasal 69 telah dijelaskan bahwa menghasut, memfitnah, mengadu domba Partai Politik, perseorangan, dan/atau kelompok masyarakat merupakan tindakan yang dilarang dalam berkampanye meskipun dengan intensitas yang sedikit. Sehingga dengan pesan yang ada pada tayangan menunjukkan bahwa masyarakat kurang teredukasi dengan baik karena pesan yang disampaikan mengandung konten kampanye hitam. 
B. Saran

1. Saran Teoritis

Dengan adanya beberapa keterbatasan dalam penelitian ini, kepada peneliti lain bagi yang ingin mengadakan penelitian sejenis lebih lanjut diharapkan untuk bisa lebih baik dan mendalam. Tidak hanya untuk menganalisis isi jumlah setiap kategori saja, namun menganalisis makna dalam konten pesan-pesan yang ada dalam masa pelaksanaan kampanye pemilihan umum, serta dengan menggunakan coder yang lebih banyak dan tidak hanya berasal dari kalangan mahasiswa namun juga dari praktisi politik.

2. Saran Praktis

Berdasarkan dari data hasil analisis yang telah diperoleh dapat terlihat bahwa dalam konten tayangan debat publik pemilihan gubernur dan wakil gubernur Jawa Barat 2018 terdapat konten pesan kampanye hitam. Dari data tersebut alangkah baiknya jika dalam pelaksanaan kampanye terutama dalam debat publik untuk kedepannya dapat membentuk tim pengawas untuk mengawasi selama debat berlangsung agar kampanye hitam tidak akan terjadi.

\section{DAFTAR PUSTAKA}

\section{BUKU}

Al-Ghazali, I. (2005). Bahaya Lisan. Jakarta: Qisthi Press.

Departemen Pendidikan Nasional. (2008). Kamus Besar Bahasa Indonesia. Jakarta: PT Gramedia Pustakan Utama.

Eriyanto. (2011). Analisis Isi: Pengantar Metodologi untuk Penelitian Ilmu Komunikasi dan Ilmu-ilmu Sosial Lainnya. Jakarta: Kencana Prenada.

Haboddin, M. D. (2017). Ketika Mahasiswa BBicara Pilkada. Malang: UB Press.

Mulyana, D. (2011). Ilmu Komunikasi Suatu Pengantar. Bandung: PT Remaja Rosda Karya Offset.

Nasrullah, R. (2015). Media Sosial. Bandung: PT Remaja Rosdakarya.

Nimmo, D. (2011). Komunikasi Politik: Komunikator, Pesan, dan Media. Bandung: Pt Remaja Rosdakarya.

Prodjodikoro, Wirjono. (2008). Tindak-Tindak Pidana Tertentu di Indonesia. Bandung: Reflika Aditama.

Subiakto, H., dan Rachmah Ida.(2012). Komunikasi Politik, Media, dan Demokrasi. Jakarta: Kencana.

Suharsaputra, U. (2012). Metode Penelitian: Kuantitatif, Kualitatif, dan Tindakan. Bandung: Refika Aditama.

Venus, A. (2009). Manajemen Kampanye. Bandung: Simbiosa Rekatama Media.

Wahid, U. (2016). Komunikasi Politik: Teori, Konsep, dan Aplikasi Pada Era Media Baru. Bandung: Simbiosa Rekatama Media.

\section{JURNAL}

Samudra, Anton Hendrik. 2011. Penegakan Hukum terhadap Tindak Pidana Penghinaan Melalui Media Siber di Indonesia (Cyber Defamation Law Enforcement in Indonesia). Surabaya: Universitas Surabaya.

Januru, La. 2016. Analisis Wacana Black campaign (Kampanye Hitam) pada Pilpres Tahun 2014. Yogyakarta: Universitas Negeri Yogyakarta.

Oktaviani, Lilian. 2015. Pengaruh Kampanye Hitam Melalui Media Massa Terhadap Pilihan Pemilih Pemula Pada Pilpres 2014 (Studi Pada Dusun Purworejo Dan Srirejo Kelurahan Branti Raya Kecamatan Natar). Lampung: Universitas Lampung.

\section{INTERNET}

hukumpidana.bphn.go.id (5 Juli 2018, pukul 19.00)

infopemilu.kpu.go.id (6 Juli 2018, 15.00)

jdih.kominfo.go.id (6 Juli 2018, 17.01)

www.pikiran-rakyat.com (10 Juli 2018, 19.17)

www.republika.co.id (18 Januari 2018, 16.31) 
